\title{
Prenatal Water Deprivation Induces Apoptosis in Sexual Dimorphic Nucleus of the Brain of Male New Born Sprague-Dawley Rats
}

\author{
Deprivación Prenatal de Agua Induce Apoptosis en Núcleos Dimórficos \\ Sexuales del Ccrebro de Ratas Sprague-Dawley Macho Recién Nacidas
}

"Shima Chehreie; "

CHEHREIE, S.; SADRI, S.; KHAZAEI, M.; GHANBARI, A.; AYUBIAN, M. \& AMIRI, S. Prenatal water deprivation induces apoptosis in sexual dimorphic nucleus of the brain of male new born Sprague- Dawley rats. Int. J. Morphol., 29(2):496-500, 2011.

SUMMARY: Considering the size of some nuclei and area, sex hormones control the sexual development of the brain. The sexual development of the brain can also be influenced by environmental stress. This study aimed to clear the effect of prenatal water deprivation on the development of sexual dimorphic nucleus (SDN) of the brain. In this research, pregnant rats were divided into two groups (control and treated). For the treated animals, water was removed from the ewes for $48 \mathrm{~h}$ at the end of third trimester of gestation (19-21 days). TUNEL staining was used for detection of apoptosis in paraffin embedded diencephalon selected sections. The ratio of apoptotic cells to non- apoptotic ones was calculated as apoptotic index. Differences of apoptotic index and serum testosterone were examined for statistical significance using Paired T- test $(\mathrm{p}<0.05)$. The apoptotic index was $0.0160 \pm .01174 \%$ for control and $0.1870 \pm .02541$ $\%$ for treated groups. The concentration of serum testosterone was $22.4 \pm 1.3$ for control and $13.37 \pm 3.3$ for treated groups. Prenatal water deprivation induces apoptosis in developing SDN nucleus of male rats that is derived by reducing the concentration of serum testosterone. The study shows the importance of low concentration acting testosterone for development of SDN nucleus that can be affected by environmental stress.

KEY WORDS: Apoptosis; Rat; SDN nucleus; Stress, TUNEL

\section{INTRODUCTION}

The brain develops differently in males and females under the influence of sex steroid hormones. The sex regions of the brain mainly exist in the hypothalamus where the most prominent of them is called medial pre-optic area (MPOA). Sexual dimorphic nucleus of POA (SDN-POA) circumscribed region within the medial part of the MPOA, of male rats exhibits about five fold greater in nuclear volume than females (Morris et al., 2004; Brann, 1995; Chung et al., 2000).

In humans and also in rats, the SDN-POA becomes sexually dimorphic as a result of prenatal hormone exposure and is not affected by steroidal environment in adulthood. Indeed, during intrauterine development, the SDN-POA is affected by testosterone according to the involvement of androgen receptor (ARs) neurons among this nucleus. Generally, testosterone binds with ARs in the cytoplasm, forms complexes and travels into cell nucleus, where it then binds with DNA to stimulate gene expression of apoptosis regulators (Mooradian et al., 1987; Arai et al., 1996; Lund et al., 2000).

It has been reported that neonatal treatment with testosterone to females was exerted on size of the SDN-POA and resulted in almost the same size between females and untreated males. Conversely, when newborn female rats are injected with tamoxifen (an antiestrogen) the volume of their SDN-POA is decreased (Vancutsem \& Roessler, 1997).

* Assistant Professor in the biology Department, Islamic Azad University, Arak Branch, Arak, Iran.

** Fertility and Infertility Research center, Kermanshah University of medical sciences, Kermanshah, Iran.

**** Associated Professor in the Fertility and Infertility Research center at Kermanshah University of medical sciences, Kermanshah, Iran.

**** Assistant Professor in the Fertility and Infertility Research center at Kermanshah University of medical sciences, Kermanshah, Iran.

****** Associated Professor in the Department of Anatomy, Tehran University of Medical Sciences, Tehran, Iran.

${ }^{* * * * * * *}$ Student Research Committee, Kermanshah University of Medical Sciences, Kermanshah, Iran. 
Prenatal stress or castration of male rats on the first day of life reduces the volume of this nucleus permanently (Kerchner \& Ward, 1992; Anderson et al., 1985). Moreover, stress induced by crowding during the final third of pregnancy, reduced sexual behavior and fertility in mice but did not alter the level of testosterone hormone in newborn mice (Crump \& Chevins, 1989). It also observed that prenatal stress and alcohol did not reduce the level of testosterone and LH hormones in male rats (Ward et al., 1996).

The present study was concerned with prenatal water deprivation on the development of SDN-POA nucleus of male newborn rats.

\section{MATERIAL AND METHOD}

Twenty inbred female Sprague-Dawley rats aged 68 weeks $(250 \pm 5 \mathrm{~g})$ were obtained from a closed bred colony at Islamic Azad University. The animals were maintained in an air-conditioned animal house at a temperature of 23-25 ${ }^{\circ} \mathrm{C}$, relative humidity at $\sim 50 \%$ and photo-cycle of $12: 12 \mathrm{~h}$ light and dark periods. The animals were provided with standard diet pellets and water ad libitum. Rats were maintained in these facilities for one week before the experiment. All experiments were carried out according to the Guidelines of the Animal Care and Use Committee of our University.

Experimental procedure. Following mating, beginning of pregnancy was determined by daily evaluation of sperm presence in vaginal smear by light microscopy analysis (ZEISS, magnification x100). Pregnant rats were divided randomly into two control and treated groups $(n=10)$. For the control animals, they were provided with both food and water. For the treated animals, water was removed from the ewes for $48 \mathrm{~h}$ at the end of third trimester of gestation (1921 days). Following delivery, the newborns were perfused via the carotid artery by a 16-gauge needle with $0.1 \mathrm{M}$ phosphate buffered saline (PBS) followed by $4 \%$ paraformaldehyde (PFA) in $0.1 \mathrm{M}$ phosphate buffer under anesthesia.

The perfusion period was about 6-8 min, and the newborns were decapitated during perfusion. The brain was removed immediately following perfusion. Post fixation was performed in the same PFA solution for $12 \mathrm{~h}$, after which the brain was placed in $20 \%$ sucrose in $0.01 \mathrm{M}$ phosphate overnight.

The paraffin blocks were prepared following routine processing protocol of paraffin preparation sampling method. Seven micrometer coronal sections were cut through the newborn brains. Diencephalic sections selected for TUNEL staining method.

TUNELAssay. Brain cell apoptosis was assessed by terminal deoxynucleotidyl transferase (TdT)-mediated deoxyUTP nick end labeling (TUNEL) assay using ApopTag alkaline phosphatase in situ Apoptosis Detection kit (Roche; 11684809910), according to the manufacturer's instructions. Following TUNEL staining, sections were counterstained with Harris Hematoxylin and mounted under glass cover slips. The sections were examined and scored under a light microscope (Nikon; YS100) equipped with a digital camera (Motic) (100X). Apoptotic index was the ratio of TUNELpositive cells to negative ones and for this purpose sections from 10 animals per group in at least 5 random fields per brain were analyzed. As negative controls, a section from each animal was processed, but terminal transferase was omitted from the TdT labeling buffer and for positive controls DNAse was added on the sections (Hsu et al., 2001).

Serum testosterone level. The serum samples were extracted with diethyl ether and allowed to freeze in a dry ice-ethanol mixture. The ether was decanted into another tube and dried under ventilation at $38^{\circ} \mathrm{C}$. The dried residue was dissolved in $0.01 \mathrm{M}$ PBS ( $\mathrm{pH} 7.4$ ) containing $0.1 \%$ gelatin. Aliquots of the PBS-gelatin-dissolved steroids were used for RIA as previously described without further chromatographic separation of testosterone (Yu et al., 1988; Hsu et al.). The sensitivity of the testosterone assay was $1.3 \mathrm{pg} /$ assay tube and the intra-assay and inter-assay coefficients of variation were 2.95 and $10.3 \%$, respectively.

Statistical Analysis. All data were analyzed using Sigma Stat (SPSS Inc, Chicago, Illinois). Apoptotic indices and the concentration of blood testosterone are presented as means \pm SEM. Differences between groups were examined for statistical significance using Paired T- test $(\mathrm{p}<0.05)$.

\section{RESULTS}

A clear difference between control and treated male newborn rats in the number of the cells of SDN-POA was confirmed. Indeed, the numbers of stained cells of SDN-POA by $\mathrm{H} \& \mathrm{E}$ were higher in control than the treated group (Figs. 1A, B).

The apoptotic cells exhibited bright labeling of fragmented nuclear DNA by TUNEL staining (Figs. 2 A and

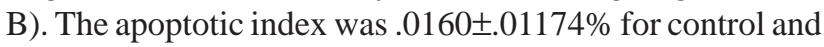
$.1870 \pm .02541 \%$ for treated groups (Fig. 2A). The concentration of serum testosterone was $22.4 \pm 1.3$ for control and 13.37 \pm 3.3 for treated groups (Fig. 2B). 

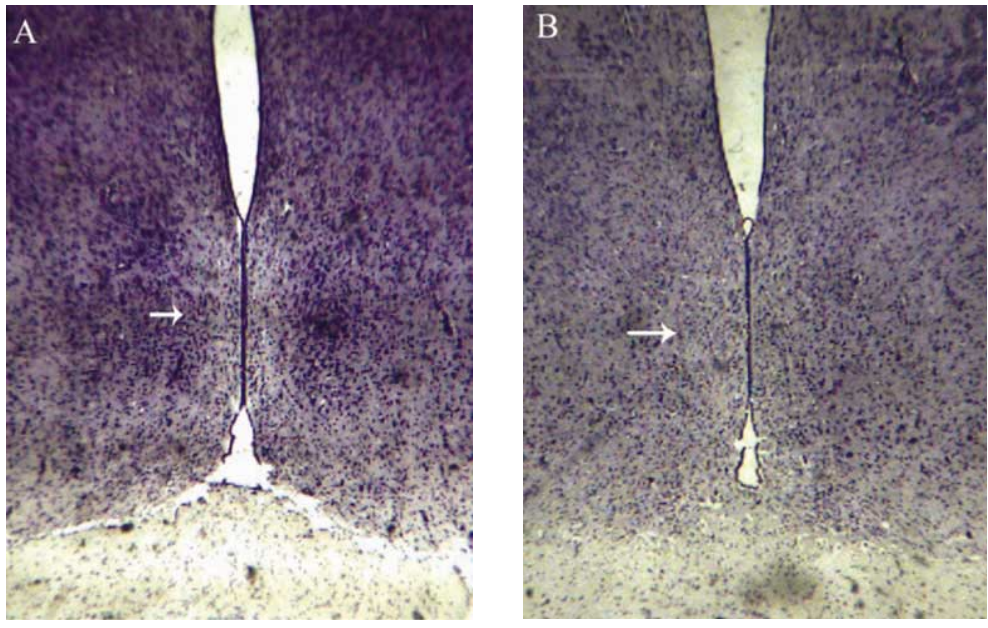

Fig. 1. The coronal section of male new born Sprague- Dawley rat in the region of sexual dimorphic nucleus (H\&E, 10X). A. None treated. B. Prenatal water deprivated. (Arrows show the nucleus in parallel with the third ventricle).
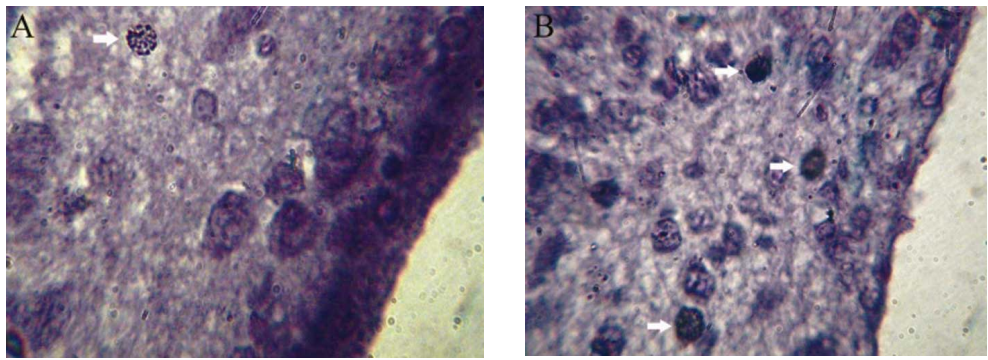

Fig. 2. The coronal section of male new born Sprague-Dawley rat in the region of sexual dimorphic nucleus (TUNEL, 100X). A. None treated. B. Prenatal water deprivated (Arrows show the apoptotic cells in parallel with the third ventricle).
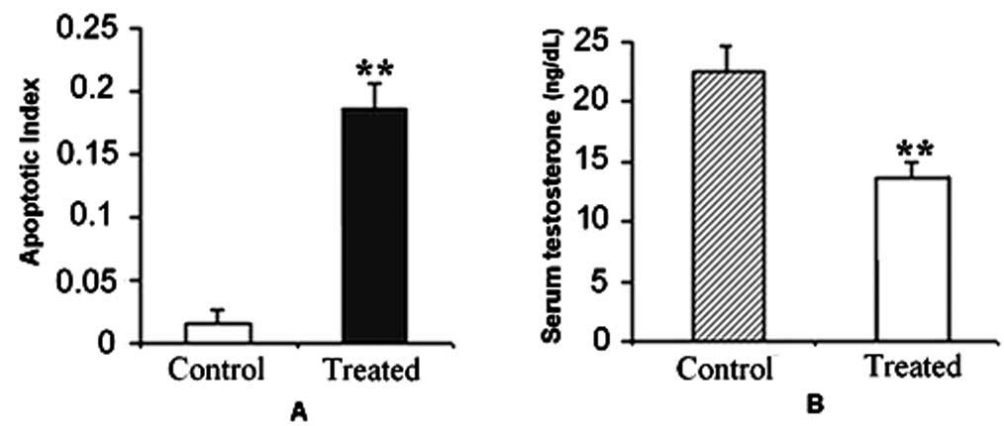

Fig. 3. Apoptotic index (A) and the concentration of testosterone (B) in none treated and prenatal water deprivated male new born Sprague-Dawley rats.

\section{DISCUSSION}

The mechanisms by which morphological sex differences arise in the central nervous system are not completely understood. Experimental and human data suggest that stresses, of either maternal or fetal origin, act in the developing embryo (Vrekoussis et al., 2010).
On female reproduction, the stress system suppresses the hypothalamic-pituitary-ovarian axis at the hypothalamic, pituitary, ovarian, and uterine levels. These include preterm birth of the offspring, low birth weight, and the development of adult diseases ranging from the metabolic syndrome to several neurodevelopmental disorders (Vrekoussis et al.). In line with these studies, our data suggest that water deprivation has an effect on the development of SDN-POA nucleus of newborn male rats.

The formation of sexually dimorphic nuclei involves the control of cell number in such nuclei by neurogenesis, neuron migration, apoptosis and differentiation (Tobet, 2002; Forger, 2006). Furthermore, previous studies showed that prenatal stress reduces the size of sexually dimorphic nucleus (Anderson et al., 1985; Rhees et al., 1999; Kerchner \& Ward).

The study in parallel with this work confirmed that water deprivation affect on the development of sexually dimorphic nucleus of males by inducing apoptosis.

Moreover, our data complete these studies by showing that the reduction of cell number is caused by apoptosis but not blocking neurogenesis, neuron migration or inducing differentiation.

It seems that the role of testosterone for development of sexually dimorphic nuclei is very important as the study showed the role of testosterone declining by prenatal stress. This data confirms Anderson et al. (1986) but is in contrast with Ward et al.

The difference in the volume of SDNPOA nucleus has been attributed by the researchers to the prevention of neurons from apoptosis developed by the influences of circulatory androgen after being converted to estrogen (Davis et al., 1996). In line with this idea, testosterone was exposed prenatally in rats that prevent apoptosis of SDN-POA nucleus of females but not in the males (Yang et al., 2004). This data confirmed that testosterone in low concentration controls the development of sexually dimorphic nuclei of males and high concentration for the females. Here we suggest that when the rats were exposed to prenatal water 
CHEHREIE, S.; SADRI, S.; KHAZAEI, M.; GHANBARI, A.; AYUBIAN, M. \& AMIRI, S. Prenatal water deprivation induces apoptosis in sexual dimorphic nucleus of the brain of male new born Sprague- Dawley rats. Int. J. Morphol., 29(2):496-500, 2011.

deprivation, the concentration of testosterone reduced from the minimum needs for masculinization of the nucleus.

Summing up, prenatal water deprivation reduces the concentration of plasma testosterone which leads to reduction of the size of sexually dimorphic nucleus. The reduction in the size of the nucleus is derived by induction of apoptosis.

ACKNOWLEDGEMENTS. We acknowledge the staff of Fertility and Infertility research center of Kermanshah.

CHEHREIE, S.; SADRI, S.; KHAZAEI, M.; GHANBARI,A.; AYUBIAN, M. \& AMIRI, S. Deprivación prenatal de agua induce apoptosis en núcleos dimórficos sexuales del cerebro de ratas Sprague-Dawley macho recién nacidas. Int. J. Morphol., 29(2):496-500, 2011.

RESUMEN: Considerando el tamaño de algunos núcleos y áreas, las hormonas sexuales controlan el desarrollo sexual del cerebro. El desarrollo sexual del cerebro también puede verse influido por el estrés ambiental. Este estudio tuvo como objetivo establecer el efecto de la privación prenatal de agua en el desarrollo del núcleo dimórfico sexual (NDS) del cerebro. Las ratas preñadas fueron divididas en dos grupos (control y tratados). Para los animales tratados, el agua se retiró de los bebederos durante $48 \mathrm{~h}$ al final del tercer trimestre de gestación (días 19-21). La técnica TUNEL se utilizó para detectar apoptosis en secciones del diencéfalo incluidas en parafina. La proporción de células apoptóticas y no-apoptóticas fue calculada como índice de apoptosis. Las diferencias del índice de apoptosis y testosterona sérica fueron examinadas para observar significación estadística mediante $\mathrm{t}$ de Student pareado (p <0,05). El índice de apoptosis fue $0,0160 \pm 0,01174 \%$ para el control y $0,1870 \pm 0,02541 \%$ para los grupos tratados. La concentración de testosterona en suero

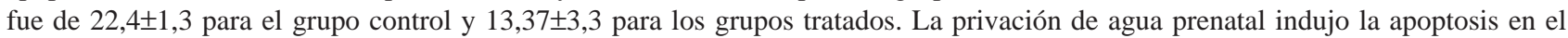
desarrollo del NDS de las ratas macho derivadas por la reducción de concentración de testosterona sérica. El estudio muestra la importancia de una baja concentración de testosterona para el desarrollo de los NDS, que pueden verse afectados por el estrés ambiental.

PALABRAS CLAVE: Apoptosis; Rata; Núcleo dimórfico sexual; Estrés; TUNEL.

\section{REFERENCES}

Anderson, R. H.; Fleming, D. E.; Rhees, R. W. \& Kinghorn, E. Relationships between sexual activity, plasma testosterone, and the volume of the sexually dimorphic nucleus of the preoptic area in prenatally stressed and non-stressed rats. Brain Res., 370(1):1-10, 1986.

Anderson, D. K.; Rhees, R. W \& Fleming, D. E. Effects of prenatal stress on differentiation of the sexually dimorphic nucleus of the preoptic area (SDN-POA) of the rat brain. Brain Res., 332(1):113-8, 1985.

Arai, Y.; Sekine, Y. \& Murakami, S. Estrogen and apoptosis in the developing sexually dimorphic area in female rats. Neurosci. Res., 25:403-7, 1996.

Brann, D. W. Glutamate: a major excitatory transmitter in neuroendocrine regulation. Neuroendocrinology, 61:2135,1995

Chung, W. C.; Swaab, D. F. \& de Vries, G. Apoptosis during sexual differentiation of the bed nucleus of the stria terminalis in the rat brain. J. Neurobiol., 43:234-43, 2000.

Crump, C. J. \& Chevins, P. F. Prenatal stress reduces fertility of male offspring in mice, without affecting their adult testosterone levels. Horm. Behav., 23(3):333-43, 1989.
Davis, E. C.; Popper, P. \& Gorski, R. A. The role of apoptosis in sexual differentiation of the rat sexually dimorphic nucleus of the preoptic area. Brain Res., 734:10-8, 1996.

Forger, N. G. Cell death and sexual differentiation of the nervous system. Neuroscience, 138(3):929-38, 2006.

Hsu, H. K.; Yang, R. C.; Shih, H. C.; Hsieh, Y. L.; Chen, U. Y. \& Hsu, C. Prenatal exposure of testosterone prevents SDN-POA neurons of postnatal male rats from apoptosis through NMDA receptor. J. Neurophysiol., 86:2374-80, 2001.

Kerchner, M. \& Ward, I. L. SDN-MPOA volume in male rats is decreased by prenatal stress, but is not related to ejaculatory behavior. Brain Res., 581(2):244-51, 1992.

Lund, T. D.; Salyer, D. L.; Fleming, D. E. \& Lephart, E. D. Pre- or postnatal testosterone and flutamide effects on sexually dimorphic nuclei of the rat hypothalamus. Brain Res. Dev. Brain Res., 120:261-6, 2000.

Mooradian, A. D.; Morley, J. E. \& Korenman, S. G. Biological actions androgens. Endocr. Rev., 8:1-28, 1987. 
CHEHREIE, S.; SADRI, S.; KHAZAEI, M.; GHANBARI, A.; AYUBIAN, M. \& AMIRI, S. Prenatal water deprivation induces apoptosis in sexual dimorphic nucleus of the brain of male new born Sprague- Dawley rats. Int. J. Morphol., 29(2):496-500, 2011.

Morris, J. A.; Jordan, C. L. \& Breedlove, S. M. Sexual differentiation of the vertebrate nervous system. Nat. Neurosci., 7:1034-9, 2004.

Rhees, R. W.; Al-Saleh, H. N.; Kinghorn, E. W.; Fleming, D. E. \& Lephart, E. D. Relationship between sexual behavior and sexually dimorphic structures in the anterior hypothalamus in control and prenatally stressed male rats. Brain Res. Bull., 50(3):193-9, 1999.

Tobet, S. A. Genes controlling hypothalamic development and sexual differentiation. Eur. J. Neurosci., 16(3):3736, 2002 .

Vancutsem, P. M. \& Roessler, M. L. Neonatal treatment with tamoxifen causes immediate alterations of the sexually dimorphic nucleus of the preoptic area and medial preoptic area in male rats. Teratology, 56(3):220-8, 1997.

Vrekoussis, T.; Kalantaridou, S.N.; Mastorakos, G.; Zoumakis, E.; Makrigiannakis, A.; Syrrou, M.; Lavasidis, L. G.; Relakis, K.; Chrousos, G. P. The role of stress in female reproduction and pregnancy: an update. Ann. N. Y. Acad. Sci., 1205(1):69-75, 2010.

Ward, I. L.; Ward, O. B.; French, J. A.; Hendricks, S. E.; Mehan, D. \& Winn, R. J. Prenatal alcohol and stress interact to attenuate ejaculatory behavior, but not serum testosterone or LH in adult male rats. Behav Neurosci., 110(6):1469-77, 1996.

Yang, S. L.; Chen, Y. Y.; Hsieh, Y. L.; Jin, S. H.; Hsu, H. K. \& Hsu, C. Perinatal androgenization prevents age-related neuron loss in the sexually dimorphic nucleus of the preoptic area in female rats. Dev. Neurosci., 26(1):5460, 2004.

Yu, J. Y. L.; Liaw, J. J.; Chang, C. I.; Lee, S. N. \& Chen, M. C. Seasonal changes in circulating levels of gonadal steroids during an estrous cycle of Holstein- Friesian cows. Bull. Inst. Zool. Academia Sinica, 27:133-43, 1988.
Correspondence to:

Ali Ghanbari, Ph. D.

Fertility and Infertility Research center

Kermanshah University of Medical Sciences

Postal code: 6714869914

P.O. Box 1568

Kermanshah

IRAN

Tel-Fax: +98-831-4281563,

Email: aghanbari@kums.ac.ir

Received: 21-12-2010

Accepted: 09-03-2011 